\title{
Flying for a buck or two: Low-cost Carriers in Aus- tralia and New Zealand
}

\author{
Sven Gross ${ }^{1}$ \\ Hochschule Harz - University of Applied Sciences
}

Michael Lück ${ }^{2}$

School of Hospitality and Tourism, New Zealand Tourism Research Institute, AUT University

\begin{abstract}
Ove er the past few decades, the traditional aviation market has seen significant developments. Traditional "legacy" carriers have been challenged by new no/low-frills, low cost carriers. While these new airlines have a relatively long history in North America, more recently they successively emerged in markets such as Europe, Asia, Oceania and Africa. The business model of low cost carriers has revolutionized air travel, and both media and academics paid ample attention to these in America and Europe. However, academic literature pertaining to the development of low cost carriers in Australia and New Zealand is scarce. Thus, this paper offers a brief history of low cost carriers in this region, and compares the business models of low cost carriers currently operating in and between Australia and New Zealand. The paper concludes that low cost carriers in this region differ from American and European low cost carriers, in part due to the geography of the countries. The main differences are the levels of in-flight service, and the fact that Australian and New Zealand low cost carriers operate on longer distances, such as coast-to-coast domestic flights in Australia, trans-Tasman flights, and flights to the South Pacific islands, and increasingly to Asia.
\end{abstract}

Keywords: Airline Competition, Air Transport and Tourism, Australia, Low Cost Carriers, New Zealand

\section{Introduction}

The business idea of low cost carriers (LCCs) has revolutionized the international aviation market. Almost all of the world's newly founded airlines are touted as low cost carriers, to signal to potential customers the prospect of less expensive air travel. The emergence of low cost carriers has transformed airline industries all around the world. Liberalized market structure policies and a general growth in aviation fostered the start-up of several low-cost airlines worldwide. As presently witnessed in South America, India, the Middle East and also Australia and New Zea-

\footnotetext{
1 Friedrichstrasse 57-59, 38855 Wernigerode, Germany, T: +493943659279, F: +4939436595279, E: sgross@hsharz.de

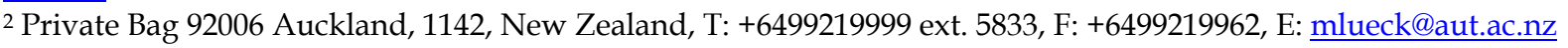


land, these new airlines take on the so called legacy carriers that have built up complex personnel and cost structures over many years of protection by regulatory regimes inviting such developments. Hence, start-up carriers do not find it difficult to enter the market on the strength of lower costs, especially regarding administrative expenses and personnel. Put differently: Today, a newly established carrier is generally a "lower cost" airline, not necessarily a "low cost" airline. While it is difficult to exactly define LCCs, Cento $(2009$, p. 19) defines an LCC as "an airline company designed to have a competitive advantage in terms of costs over a FSC", and T2Impact and Flight Insight (2008, p. 28) note that common points of definition are based on "service and operational rules, such as lack of inflight food, direct distribution and a single aircraft type". However, airlines tend to break such rules, depending on their operating environment. Harbison and McDermott $(2009$, p. 27) identify these factors as

- High seating density

- High aircraft utilisation

- Single aircraft type

- Low fares, including very low promotional fares

- Predominant usage of internet-based booking

- Single class configuration

- Point-to-point services

- No (free) frills

- Predominantly short- to medium-haul route structures

- Frequent use of second tier airports

- Rapid turnaround time at airports

The main factor that all LCCs have in common though, is simplicity, which in turn reduces cost (T2Impact and Flight Insight, 2008). In order to be competitive, many network/legacy carriers introduced some of the LCC attributes, such as a simpler fare structure (such as Air Canada's three fares structure in domestic economy class) or extreme promotional fares, such as Air New Zealand's grabaseat fares (starting at \$NZ 1 including all fees and taxes).

In the past years throughout North America and Europe, airlines launched as low cost carriers were mostly able to establish themselves quickly in the market due to the inflated cost structures of their traditional competitors. In addition, changes in consumer preferences favoured these low cost carriers. Generally, consumers had fared well with discount products in other markets (e.g. last minute travels, electronic products, hotels). However, in North America and Europe (for the most part) incumbent carriers have been able to come to grips with attacks from a host of start-up airlines, successfully resorting to cost cutting schemes that could bring about a reduction of much of the initial differences in costs and, in turn, prices. Today, consumers opting for traditional airlines are generally able to purchase cheap tickets, usually by taking advantage of offerings of unsold seats available from the airlines' homepages. However, the market share of European LCCs has grown steadily since their inception, at the expense of scheduled and charter airlines. In 2000, LCCs had a market share of 5\%, while scheduled airlines had a $75 \%$ market share (Teckentrup, 2009). With the rapid increase in LCCs, their market share grew to an estimated market share of $40 \%$ in 2010, while scheduled airlines lost a third of their market share (Figure 1). Charter airlines lost half of their market share as well, but this figure has to be interpreted with caution, since many traditional charter carriers in Europe evolved into hybrid airlines, with a mix of charter and LCC characteristics. 


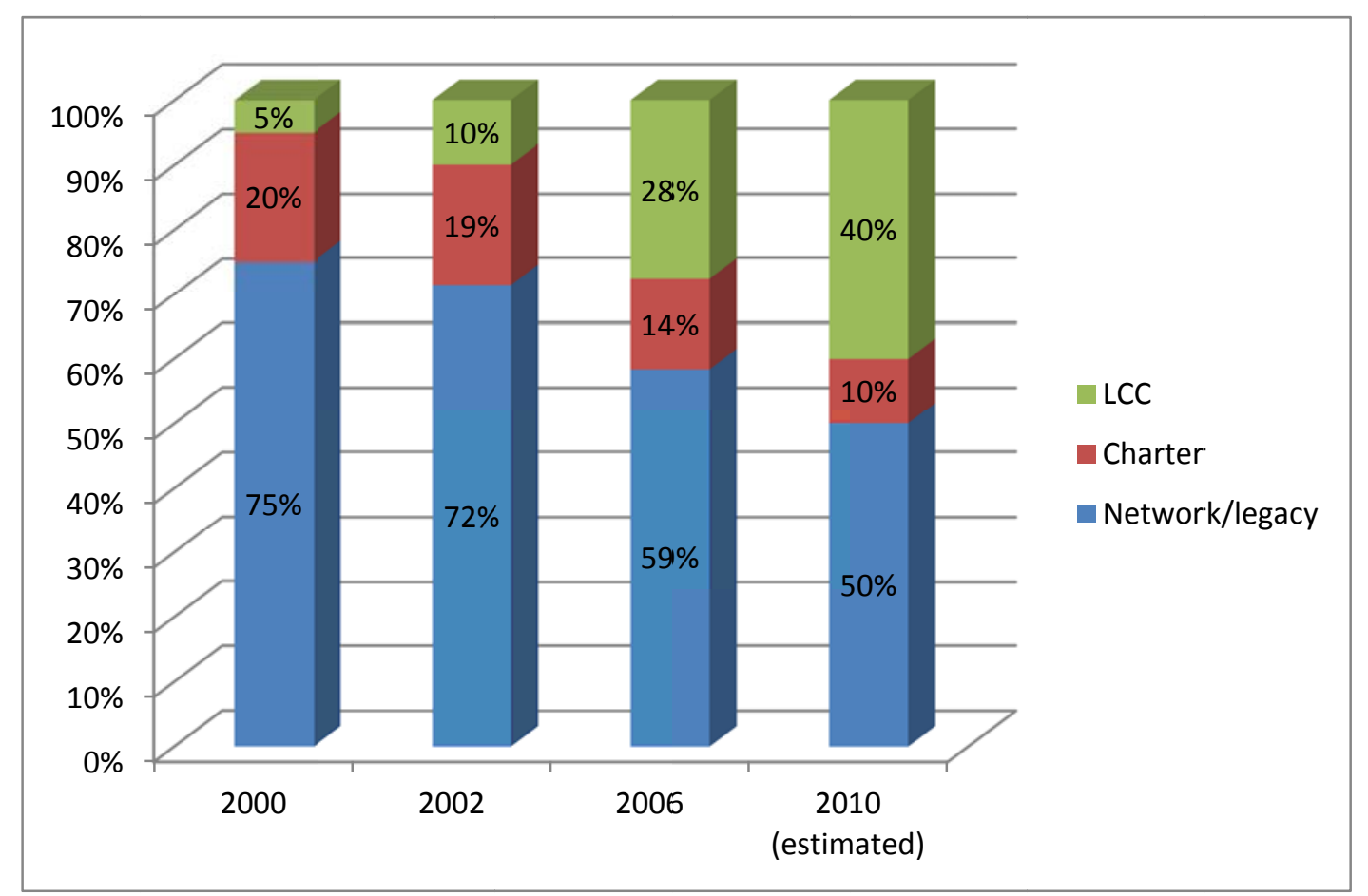

Figure 1. Market share in the European Air Traffic (available seats)

Source: After Teckentrup (2009, p. 191)

The USA and Europe already established low-cost airlines in the 1970's and 1990's, respectively. The low-cost industry in Oceania (including Australia and New Zealand) has not been widely developed until the beginning of this century, but has shown dramatic growth ever since, which is why today the low cost market accounts for $12 \%$ of the total flight activity in the Asia/Pacific region (including China and India), compared to $22 \%$ in Europe and $18 \%$ within North America. Figure 2 illustrates the rapid growth in Oceania, from 136 weekly low-cost flights in 2000 to 1,340 weekly flights in 2003 , an increase of $885 \%$. This enormous growth slowed in the past few years, but there was still an increase of 199\% from 2003 to 2005 (Boeing, 2007).

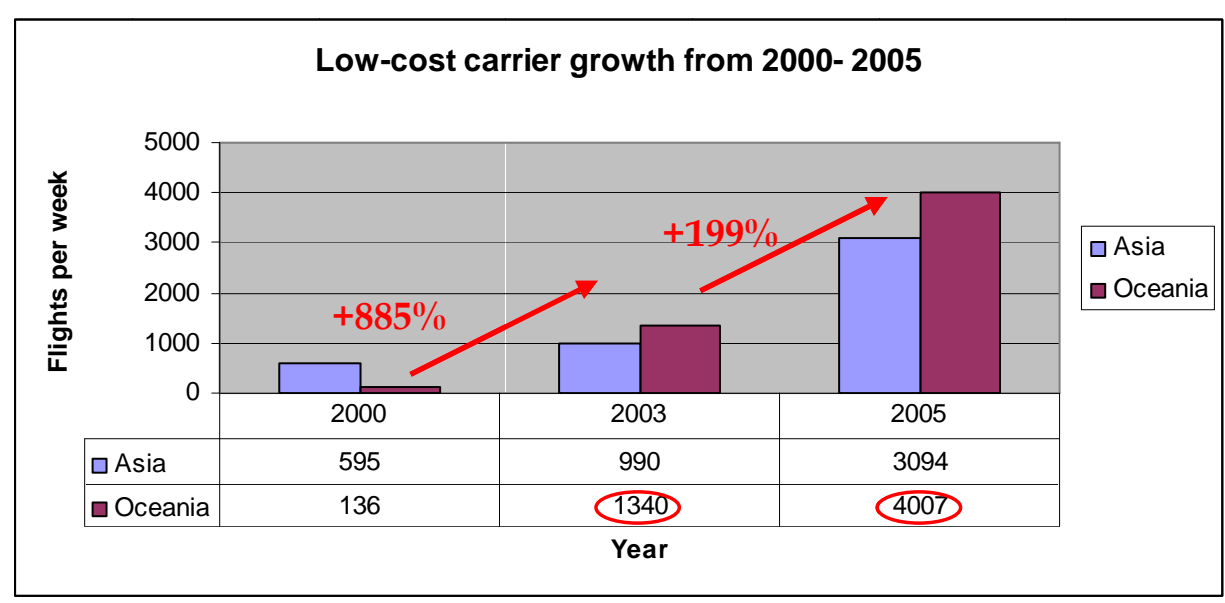

Figure 2. Low-cost Carrier Growth from 2000 - 2005

Source: Boeing (2007) 


\section{Aim and Methodology}

The aim of this paper is to examine the different low cost carriers already having entered the markets in Australia and New Zealand, and to give an outlook on possible future developments. Low cost carriers have been largely analyzed and discussed controversially in the press and among economists and scientists. Studies specifically related to low cost airlines in Australia and New Zealand are scarce, and in Europe mostly unheard of. Thus, this paper examines the business model of each carrier, contrasting the characteristic criteria of low cost carriers in Europe and Australia/New Zealand.

This study is based on a market and business model analysis using primary and secondary sources. The secondary sources are mostly freely available data and information from newspaper and trade journal articles, studies of organizations, consulting companies and banks, field reports of private persons and journalists as well as publications and websites of the various airlines.

A business model is the description of the way in which a company, a corporate system or an industry creates value on the market. According to Bieger and Agosti (2006, pp. 47-49), this requires answers to questions such as:

- Which benefits arise for which customer (groups) (product/service concept) and how is this benefit communicatively anchored (conveyed?) in the relevant market (communication concept)?

- How are the revenues generated (revenue/pricing concept), and which growth concept is pursued?

- Which core competencies are necessary (competence configuration)?

- What are the strategic factors for success?

- How is the business model implemented regarding the different processes and the marketing mix?

- Which partners are selected (cooperation concept, e.g. airports)?

\section{The Aviation Profile in Oceania}

\section{Significance of Tourism and Air Travel}

Market liberalization policies have enabled continued economic growth in Australia and New Zealand in the last ten years. Travel and tourism have become key economic drivers for both the Australian and the New Zealand economies. In Australia, tourism directly employs $5.6 \%$ of the workforce, contributes $3.7 \%$ of the GDP and is worth around $11 \%$ of exports. In New Zealand, tourism directly or indirectly employs $9.8 \%$ of the workforce, contributes $9 \%$ of the GDP and $18.7 \%$ of New Zealand exports (PhoCusWrigt, 2007).

Oceania's population is spread over a relatively large area of land and sea, which is why people rely heavily on aviation to get from place to place. Especially in Australia, with many regions being remote and desert, flying is the most convenient transport option for reaching many parts of the country. Table 1 substantiates this fact by comparing the approximate travel times from Sydney to other major cities by the different means of transport. In addition, LCCs do not have to compete with, for example, a high speed rail network.

New Zealand has been Australia's number one source market since 1999. In the year ending September 2008, Australia received 1,000,417 visitors from New Zealand, which was the largest source of visitors, followed by the United Kingdom $(637,943)$, Japan $(458,428)$ and USA $(432,364)$ 
(Tourism Australia, 2008a). Conversely, Australia is New Zealand's largest and steadily increasing inbound tourism market. In 2008, almost 40 per cent of all arrivals originated in Australia, amounting to a total of 969,099 visitors, which is an increase of $2.5 \%$ from the previous year. In the future visitor arrivals are expected to rise on average by $4 \%$ annually (from 2008-2014) (Tourism New Zealand, 2008).

The tourism trends observed in Australia and New Zealand are broadly similar. The transTasman aviation route (between New Zealand and Australia) is Australia's and New Zealand's busiest in terms of capacity and frequencies. Seat capacity peaked in 2005, following the entrance of Emirates, Jetstar and Pacific Blue. Emirates in particular added a large amount of seats on the trans-Tasman routes, culminating in the introduction of the A380 on the Sydney-Auckland services. In addition to Emirates, Aerolineas Argentinas and LAN Chile also use $5^{\text {th }}$ Freedom rights (the right of an airline to carry payload between two foreign countries, as long as the flight originates or terminates in the country where it is registered) by adding Auckland-Sydney-Auckland flights to their Buenos Aires-Auckland and Santiago-Auckland services, respectively, while Royal Brunei offers Brisbane-Auckland-Brisbane connections as add-on to their Bandar Seri BegawanBrisbane flights. Air New Zealand remains the dominant airline on the trans-Tasman route (42\%), while Qantas operated around 19\% (including services operated by JetConnect, a subsidiary of Qantas) of all flights in 2007, Freedom Air 9\%, Pacific Blue 8\%, and Jetstar 6\% (Table 2).

Table 1. Vehicle Travel Times (hours) from Sydney to Other Major Cities in Australia

\begin{tabular}{llll}
\hline & Air & Rail & Coach \\
\hline Canberra & 0.45 & 4.00 & 5.00 \\
Adelaide & 1.40 & 25.00 & 22.00 \\
Brisbane & 1.20 & 15.00 & 15.00 \\
Darwin & 5.00 & - & 92.50 \\
Melbourne & 1.10 & 10.00 & 14.00 \\
Perth & 4.00 & 65.00 & 56.00 \\
Hobart & 2.05 & - & - \\
\hline
\end{tabular}

Source: Allo' Expat (2009)

Table 2. Trans Tasman Aviation Market Share 2007

\begin{tabular}{llllll}
\hline Airline & $\mathbf{2 0 0 3}$ & $\mathbf{2 0 0 4}$ & $\mathbf{2 0 0 5}$ & $\mathbf{2 0 0 6}$ & $\mathbf{2 0 0 7}$ \\
\hline Air New Zealand & $37 \%$ & $36 \%$ & $40 \%$ & $42 \%$ & $42 \%$ \\
Qantas & $33 \%$ & $28 \%$ & $25 \%$ & $21 \%$ & $19 \%$ \\
Emirates & $3 \%$ & $7 \%$ & $8 \%$ & $9 \%$ & $11 \%$ \\
Freedom Air & $18 \%$ & $15 \%$ & $13 \%$ & $10 \%$ & $9 \%$ \\
Pacific Blue & $0 \%$ & $6 \%$ & $7 \%$ & $7 \%$ & $8 \%$ \\
Jetstar & $0 \%$ & $0 \%$ & $0 \%$ & $6 \%$ & $6 \%$ \\
Other & $9 \%$ & $8 \%$ & $7 \%$ & $5 \%$ & $5 \%$ \\
Total & $100 \%$ & $100 \%$ & $100 \%$ & $100 \%$ & $100 \%$ \\
\hline
\end{tabular}

Source: Tourism Australia (2008b)

"Qantas and Freedom Air both lost market share to the relatively new entrants Pacific Blue, Jetstar and Emirates. In 2007, direct capacity on the New Zealand-Australia route fell $6 \%$ year-onyear, while load factors increased 8 percentage points. Capacity reductions were led by the Air NZ group (with Freedom Air down 18\%) in early 2007 and the suspension of Qantas' AucklandAdelaide services in July 2007. Jetstar and Pacific Blue were the only two carriers to increase capacity on this route in 2007" (Tourism Australia, 2008b). 


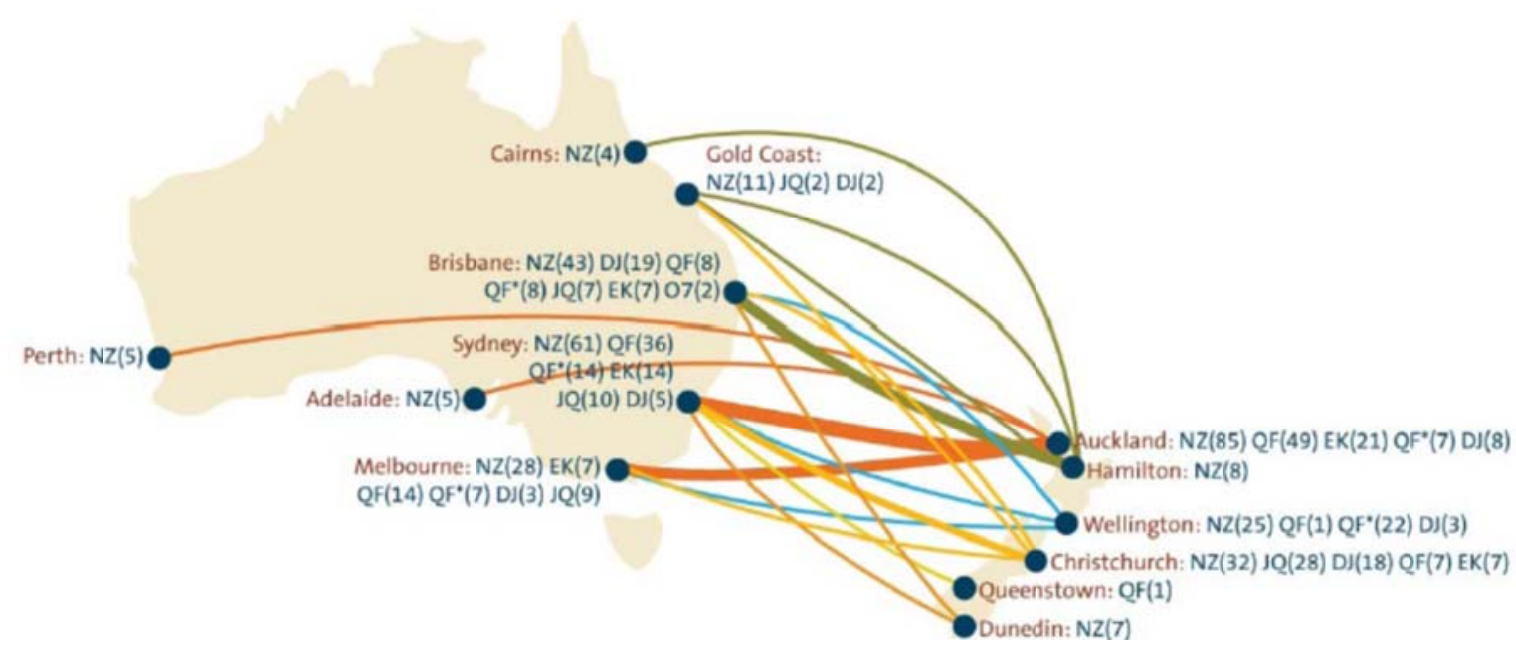

Key: NZ = Air New Zealand, QF = Qantas (including its subsidiary *JetConnect), DJ = Pacific Blue, EK $=$ Emirates, JQ $=$ Jetstar

Figure 3. Direct Services Across the Tasman Sea

Source: Tourism Australia (2008b)

\section{Airports in Australia and New Zealand}

Australia has a good complement of airports, both international and domestic, as well as many smaller, regional terminals (88 airports in total) ${ }^{3}$. With each state capital including at least one major international airport, all important urban centers have been made easily accessible. Sydney's International Airport is Australia's premier airport (Figure 4), with approximately 30 million passengers arriving and departing from this airport every year. It accounts for $45.4 \%$ of total international passenger movements, $23.4 \%$ of total domestic movements and $18.9 \%$ of total regional passenger movements. In 2007-08 all Australian airports recorded increases in passenger movements compared to 2006-07 (BITRE, 2008b).

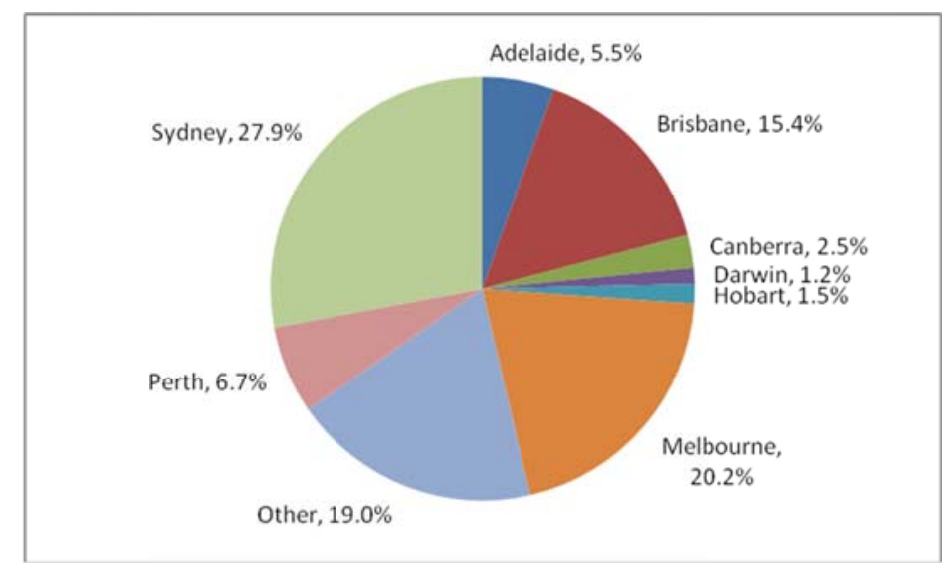

Figure 4. Airport Shares in Air Passenger Movements 2005-06

Source: BITRE (2008b)

\footnotetext{
3 The top ten airports are: Sydney, Melbourne, Brisbane, Perth, Adelaide, Gold Coast, Cairns, Canberra, Hobart
} and Darwin (BITRE 2008a, p. 4ff.). 
New Zealand offers a total of 36 international and domestic airports. Auckland airport, New Zealand's largest and busiest airport based on total passenger numbers, serves approximately $70 \%$ of the international arrivals and departures. Airports in Wellington, Christchurch, Dunedin, Queenstown, Hamilton and Rotorua also receive flights from other countries. Wellington International Airport is a major domestic hub in the regional and national transport system, as well as providing international services to Sydney, Melbourne and Brisbane (Tourism New Zealand, 2009).

\section{The Emergence of Low Cost Carriers in Australia and New Zealand}

Over the past four decades the passenger aviation industry has been subjected to several waves of innovations. Three very important innovations are the political liberalisation in the 1970s and 1980s, the rise of LCCs, and the widespread application of the Internet. "Perhaps no international air travel market has been more radically affected by these innovations than the set of transTasman routes linking the major cities of Australia and New Zealand. Few aviation markets are now so open to competition, including competition from airlines based in third countries. Furthermore the relatively short (three to four hours) and simple (point-to-point) nature of the product has facilitated the entry of low cost carrier services and encouraged the adoption by consumers of 'do it yourself' comparison shopping on the internet" (Hazledine, 2008, p. 337).

The deregulation of domestic aviation in New Zealand commenced in 1983 and was completed in 1990 with the abolition of air services licensing. In 1986, New Zealand already allowed up to $100 \%$ foreign ownership of domestic airlines. Australia initiated the deregulation process in 1990 and successfully completed it in 1995. Prior to this, Qantas and Ansett dominated the market (Forsyth, 2003). The deregulation of Australia's domestic airlines meant that flight services were getting more competitively priced (BITRE, 2006; Francis et al., 2006; Statistics New Zealand, 2009).

The majority of LCC development in the region has taken place on the trans-Tasman route, as well as domestically in Australia and New Zealand. Thus, this paper will focus on these areas.

Developments in the past years are characterized by airlines entering and withdrawing from the various international markets (Table 3). Some of the airlines were founded as low cost subsidiaries of traditional airlines (e.g. Jetstar by Qantas, and Freedom Air by Mount Cook Airlines, a $100 \%$ subsidiary of Air New Zealand) in order to react to offers of emerging low cost carriers. Air New Zealand's creation of Freedom Air through Mount Cook Airlines was a direct response to the market entrance of Kiwi Airlines in the mid-1990s. Freedom Air inaugurated operations out of Dunedin and Hamilton, the gateways Kiwi Airlines used. Without the intervention of the Ministry of Transport, and with almost endless resources (through the parent company Air New Zealand), they were able to undercut fares and fly at a loss, whereas Kiwi Airlines had to make money. Ewan Wilson, CEO of Kiwi Airlines, reflects: "Air New Zealand knew exactly what cost structures were involved in running an airline, and deliberately and calculatedly set up Freedom Air and sat back and watched and waited" (Wilson, 1996, p. 164). And it was indeed just a matter of time, until they had successfully pushed Kiwi Airlines out of the market, and into liquidation.

Important recent developments in Australia are the new entrants Virgin Blue, Jetstar, and Tiger Airways. Virgin Blue was founded in August 2000 and has grown into Australia's second-largest airline (by fleet size). Jetstar commenced flying in May 2004 on some trunk routes, and on some routes from secondary airports (BITRE, 2006; Forsyth, 2007). Qantas established Jetstar as a tool to antagonize the rise in the domestic Australian market of Virgin Blue (Qantas Airways, 2007). Tiger Airways, a subsidiary of Tiger Aviation (partly owned by Singapore Airlines), entered the market in November 2007 with services in the Australian domestic airline market. The airline is 
based in Melbourne, with its main hub at Melbourne Airport and established a secondary hub at Adelaide Airport in 2009 (BITRE, 2008b).

Table 3. Developments in the Australia/New Zealand low cost market (1990-2009)

\begin{tabular}{|c|c|c|c|c|c|}
\hline Name & $\begin{array}{ll}\text { Country } & \text { of } \\
\text { origin (base) }\end{array}$ & $\begin{array}{l}\text { Year of } \\
\text { foun- } \\
\text { dation }\end{array}$ & $\begin{array}{l}\text { Start of flight } \\
\text { operations }\end{array}$ & $\begin{array}{l}\text { Withdrawal } \\
\text { from the } \\
\text { market }\end{array}$ & $\begin{array}{l}\text { Parent/holding } \\
\text { company }\end{array}$ \\
\hline $\begin{array}{l}\text { Compass Air- } \\
\text { lines }\end{array}$ & Australia & 1990 & 1990 & 1991 & \\
\hline $\begin{array}{l}\text { Compass Air- } \\
\text { lines II }\end{array}$ & Australia & 1992 & 1992 & 1993 & \\
\hline Impulse Airlines & Australia & 2000 & 2000 & May 2004 & $\begin{array}{ll}\text { (acquired } & \text { by } \\
\text { Qantas 2001) } & \end{array}$ \\
\hline Virgin Blue & Australia & 2000 & 2000 & - & $\begin{array}{l}\text { Virgin Blue Hold- } \\
\text { ings Limited }\end{array}$ \\
\hline Jetstar Airways & Australia & 2003 & May 2004 & - & Qantas Airways \\
\hline $\begin{array}{l}\text { Tiger Airways } \\
\text { Australia }\end{array}$ & Australia & $\begin{array}{l}\text { March } \\
2007\end{array}$ & $\begin{array}{l}\text { November } \\
2007\end{array}$ & - & Tiger Aviation \\
\hline $\begin{array}{l}\text { Kiwi Travel } \\
\text { International } \\
\text { Airlines }\end{array}$ & New Zealand & 1994 & 1994 & $\begin{array}{l}\text { September } \\
1996\end{array}$ & \\
\hline Freedom Air & New Zealand & 1995 & 1995 & March 2008 & Air New Zealand \\
\hline CityJet & New Zealand & 1999 & May 1999 & $\begin{array}{l}\text { November } \\
1999\end{array}$ & \\
\hline K2000 & New Zealand & 2000 & & 2000 & $\begin{array}{l}\text { Central Pacific } \\
\text { Airlines }\end{array}$ \\
\hline Pacific Blue & New Zealand & 2003 & 2004 & - & Virgin Blue \\
\hline
\end{tabular}

Source: own compilation based on airline websites (status: February 2009); Flight International (2008)

Pacific Blue was founded in 2003 and commenced operations mainly out of Christchurch. Pacific Blue is a subsidiary of Virgin Blue, and was launched in order to position itself as a low fare competitor to Air New Zealand and Qantas on trans-Tasman routes. In August 2007, Pacific Blue initiated services within New Zealand, and has remained a true low cost carrier. Although Pacific Blue is an Australian airline there are no capacity constraints between the two nations, based on the current air services agreement. Carriers can operate unlimited services between the two countries (Ministry of Transport New Zealand, 2007).

\section{Components of the Business Model}

A close look at the airline industry shows that there is a wide range of different implementations of the low cost strategy, and that the boundaries between traditional and low cost carriers are blurred. Despite the low cost concept being implemented by various low cost carriers at different levels of intensiveness, and by means of different tools and concepts, it is possible to establish a common basic business model for low cost carriers (Figure 5). The many configuration opportunities of the single business components will be analyzed further for the airlines, which operate 
within Australia and New Zealand, and/or offer trans-Tasman flights. Subjects of procurement and suppliers, as well as process management and marketing, and opportunities of their practical implementation will be pointed out.

The central element of a low cost strategy is a continuous analysis and control of the most important costs within a company and an efficient asset management. Therefore the product, distribution and communication policies, in addition to the pricing policy, need to be considered.

\section{Procurement}

\section{Aircraft}

Aircraft can be procured through purchase or leasing of both newly-manufactured and used airplanes. To finance their planes and required technical equipment, low cost carriers mainly use the leasing option. An important factor for the success of the low cost segment in Europe was the opportunity to buy second-hand aircraft. In the aftermath of the worldwide aviation crisis following September 11th, 2001, many used airplanes were available on the international market at very low prices (Bjelicic, 2004). LCCs in Australia and New Zealand often started operations with leased and/or owned second-hand aircraft. In some cases they operated aircraft of their parent airline's fleets (e.g. Jetstar, JetConnect, Pacific Blue). However, these airlines increasingly purchase brand new aircraft from the manufacturers, supported by good deals due to high order numbers. In some cases, the airlines sell their new aircraft to a leasing company, and lease them back. The trend to the purchase or lease-back of new aircraft results in young fleets, which has positive effects on the operating costs (e.g. fuel efficiency, reliability, maintenance cost).

Lean Management, i. e. lean and cost-efficient business management (concentration on core competencies and outsourcing). Alignment of all processes and activities on optimizing and reducing costs, with the exception of the sensitive safety subject.

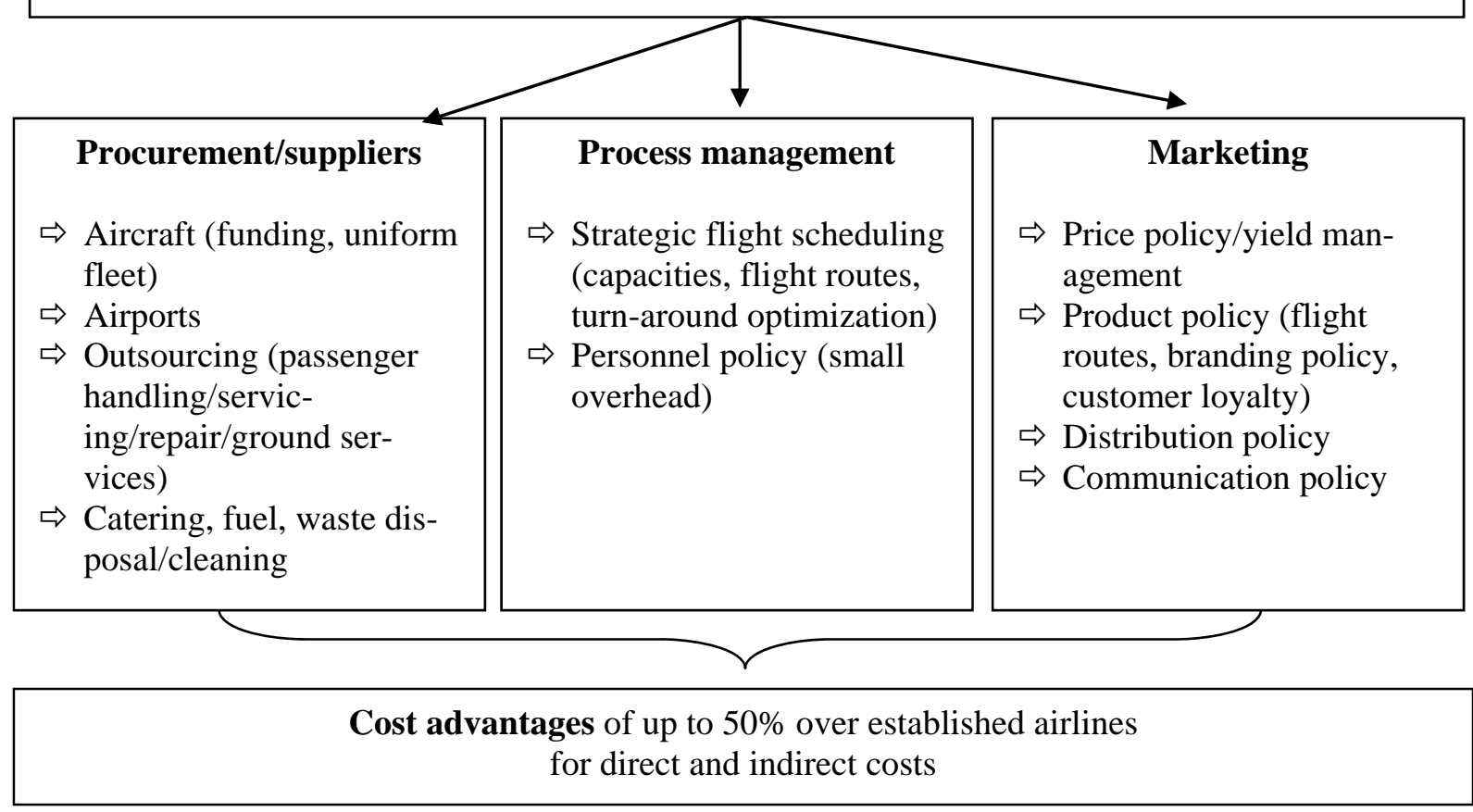

Figure 5. The Business Model of (European) Low Cost Carrier

Source: Gross and Schroeder (2007, p. 34) 
Low cost carriers in Europe placed huge orders with manufacturers over the last few years. The airlines Ryanair, easyJet, Air Berlin, Flybe and germanwings alone ordered more than 330 new airplanes in 2005 and enjoyed large discounts (Stirm and Schmidt, 2005). Such discounts may be used by airlines to sell a certain number of the aircraft to leasing companies and lease them back. This would allow them to achieve a net profit of several million dollars per jet (Goettert and Schmidt, 2005). More recently, bulk orders have also been noted by LCCs in Australia. For example, Qantas has confirmed that a total of 53 aircraft have been earmarked for its low cost subsidiary Jetstar (Business Day, 2009). A uniform fleet of the same aircraft type leads to cost savings for personnel training and more flexible operational planning, as flight and technical staff are subject to identical qualification standards. This also allows cost savings in the field of maintenance and servicing, for example with respect to spare part stock management. However, disadvantages may arise due to dependence on a sole manufacturer (supplier power). Also, flight scheduling advantages for low cost carrier result from a uniform fleet, since the different performance features and capacities of various aircraft types need not be taken into account. However, any possible variation in demand is impossible or difficult to compensate due to rigid capacities. The use of uniform aircraft in Australia and New Zealand, such as B737-800 and A320, is noticeable with LCCs operating in the present market (Table 4).

Table 4. Fleet Structure

\begin{tabular}{|c|c|c|c|c|}
\hline Name & $\begin{array}{l}\text { Number of air- } \\
\text { craft }\end{array}$ & $\begin{array}{l}\text { Number and type of } \\
\text { aircraft }\end{array}$ & $\begin{array}{l}\text { Different } \\
\text { types }\end{array}$ & Orders \\
\hline Virgin Blue & 68 & $\begin{array}{l}22 \text { B737-700 } \\
28 \text { B737-800 } \\
6 \text { Embraer } 170 \\
12 \text { Embraer } 190\end{array}$ & $\begin{array}{l}2 \text { main types } \\
(2 \text { sub-types } \\
\text { each })\end{array}$ & $\begin{array}{l}9 \text { Boeing 737-800 } \\
6 \text { Embraer } 190\end{array}$ \\
\hline Jetstar Airways & 34 & $\begin{array}{l}31 \text { A } 320-200 \\
2 \text { A321-200 } \\
6 \text { A330-200 }\end{array}$ & $\begin{array}{l}2 \text { main types } \\
\text { (2 sub-types) }\end{array}$ & $\begin{array}{l}53 \text { A } 320-200 \\
16 \text { A321-200 } \\
1 \text { A330-200 } \\
15 \text { B } 787-800\end{array}$ \\
\hline $\begin{array}{ll}\text { Tiger } & \text { Airways } \\
\text { Australia } & \end{array}$ & 5 & 5 A320-200 & 1 & 2 Airbus A319-100 \\
\hline Pacific Blue & 10 & 10 B737-800 & 1 & - \\
\hline
\end{tabular}

Source: own compilation based on airline websites (status: February 2009); Flight International (2008)

\section{Airports}

Airports are an important element within the business model of European LCCs, since they provide the necessary infrastructure. Savings on fees are often directly negotiated between the airlines and the respective airport, and may include various quantity discounts or marketing grants 4 . Although the negotiated fees do not allow all airports to cover their costs, they sometimes agree to the conditions dictated by a LCC because of the beneficial direct and indirect economic effects for the airport and the surrounding region. Encouraged by the rapid growth of LCCs, some airports market themselves as a LCC base, such as the airport Cologne/Bonn, which

\footnotetext{
${ }^{4}$ With regard to subsidies, the EU adopted new regulations in September 2005 according to which financial incentives shall still be allowed, but within narrow bounds:

a) Subsidies must not be paid for the ordinary flight operation of an airline, but only for start-up costs of new routes (depending on the specific airport, $30-50 \%$ of these expenses may be reimbursed).

b) Refunding shall be limited to a period of three years, for particularly less-favoured regions to five years.

c) Only regional airports with less than 5 million passengers shall be allowed to pay financial incentives, in exceptional cases, such as business slumps, also airports with 5-10 million passengers (Pranger, 2005).
} 
doubled their passenger numbers from $5.4 \mathrm{~m}$ in 2002 to $10.5 \mathrm{~m}$ in 2007. This growth is mainly based on LCCs, for example, germanwings (with its headquarter at the airport), TUIFly, Wizz, and easyJet (Graham, 2003; Harbison and McDermott, 2009). In 2008, 63 to 65\% of Cologne/Bonn's passengers were passengers on LCCs (DLR and ADV, 2008; Harbison and McDermott, 2009). However, increasingly LCCs are being criticized for the pressure they put on secondary airports. For example, Ryanair asked Tallinn (Estonia) airport to lower the airport fees to zero for 950,000 pax and more, and in return offered to double passenger numbers (about 1.5 million additional pax per annum) (Tere, 2010). In a public campaign, easyJet lobbied for lower airport charges at Luton airport. Their newspaper advertisements argue that 1,000 jobs would be at risk due to the increased airport charges (Airobserver, 2009).

Even major airports experience pressure by LCCs. Manchester, the $4^{\text {th }}$ largest airport by passenger numbers in the United Kingdom, received an offer by Ryanair to increase its current network of ten cities by 28 additional weekly flights in return for zero passenger charges instead of currently $£ 3$. Manchester Airport refused this offer, resulting in Ryanair withdrawing nine out of the ten services (Harbison and McDermott, 2009). Many airports today are fully dependent on LCCs, and some even on one single airline. The airport Frankfurt-Hahn, located some 150 kilometers outside of Frankfurt in a very rural area, is a former air force base that has been converted into a civilian airport. In 2007, 95 per cent of the 3.5 million annual passengers traveled with Ryanair. In addition, the remaining 5\% are LCC passengers as well (Harbison and McDermott, 2009). The Low Cost Monitor 2/2008 (DLR and ADV, 2008) notes that in 2008, Ryanair served $100 \%$ of the passengers at Hahn - a fact that well underlines the dependency of an airport on one single airline (Horbert, 2007). In Australia, the airport in Newcastle, New South Wales, has ranked $34^{\text {th }}$ among the world's fastest growing airports (>500,000 pax), with an increase from 459,572 passengers in 2004 to $1,110,607$ passengers in 2008 , which represents a growth rate of $142 \%$. The LCC Jetstar is the dominant carrier at Newcastle airport, having a capacity share of 65\% (Harbison and McDermott, 2009). Jetstar is also the major player at Melbourne's secondary airport Avalon. With only one small competitor (Sharp Airlines), Jetstar undoubtedly provides the majority of the one million passenger capacity at Avalon (Avalon Airport, 2010). Concrete figures from LCCs in New Zealand are not known to the authors, but it is less likely that major airports will agree on concessions, given these airports are served by at least one of the network carriers (Air New Zealand and/or Qantas, plus a variety of foreign carriers in Christchurch and Auckland), and thus are not solely dependent on LCCs.

\section{Outsourcing, Catering, Waste-disposal, Fuel}

Since most low cost carriers do not have the required economies of scale, technical services such as maintenance and repair are outsourced to specialists who are able to carry out these jobs with greater cost-effectiveness, thus avoiding extra fixed costs for the airline company (Pompl, 2007; Doganis, 2001). Also, passenger handling and other ground services ("ground handling") are assigned to external handling agents. This allows LCCs to drastically reduce station facilities and staff. It is therefore typical for LCCs in Europe to incur low costs for ground staff and office/waiting rooms (Doganis, 2001). Some airlines have gone a step further by introducing automatic and/or Internet check-in procedures (e.g. Air Berlin, dba, easyJet, germanwings). Check-in via mobile phone (e.g. Air Berlin via MMS-capable mobile) or SMS Seat Reservation have been introduced by some LCCs in Europe as well. Such measures would also be easy to implement for LCCs in Australia/New Zealand; however, it is not yet used by airlines to the same extent. In contrast, Jetstar's ground handling services are provided by its parent Qantas, and Tiger Airways contracts Singapore Airlines with maintenance services (Qantas, 2008; Tiger Airways, 2009).

Although catering included in the fare is mostly not provided by European LCCs, a selection of food and drinks is often offered for purchase. This does not only allow savings of catering costs, but generates additional revenue. Another positive effect is generated by reduced turnaround 
times of airplanes, since less time is needed for loading. Catering is not complimentary on most Australian/New Zealand LCCs, with the exception of Jetstar, which includes food and beverages in its StarClass fares (Table 6). Cost savings are also achieved by European LCCs with respect to waste collection and cleaning inside the cabin, since these services are partly undertaken by cabin staff, thus saving costs for external ground-handling contractors. Such cleaning duties could also be undertaken by the cabin crew on flights in Australia/New Zealand.

\section{Process Management}

\section{Strategic Flight Scheduling}

The established airlines focus on network-based structures while European LCCs concentrate on point-to-point operations between passenger-intensive economic centers. Airports are mainly offered in parallel markets, i.e. cities with several airports which are not yet being served by competitors, or secondary airports near larger economic centers (Pompl, 2007). Because they use mainly secondary airports with no capacity restrictions, and without congestion, LCCs usually do not have problems in obtaining slots. Table 5 provides an overview of the LCCs in Australia/New Zealand, the network configuration and their destinations and routes.

While Jetstar offers point-to-point services only, Virgin Blue, Pacific Blue and Tiger Airways also offer connecting flights. Virgin Blue/Pacific Blue provide connections to Hawai' $i$, and within Australia ${ }^{5}$, New Zealand and between both countries (connecting flights from Virgin Blue and Pacific Blue). Virgin Blue and Hawaiian Airlines signed an interline agreement, which "will enable travel agents to issue a single ticket for travel on both airlines, from anywhere in the Virgin Blue network to anywhere in the Hawaiian Airlines network. It will also enable Hawaii-bound passengers around Australia to check their luggage all the way to Honolulu when they check in for their Virgin Blue connecting flight" (Virgin Blue, 2006).

Table 5: Destinations, Routes and Network Configurations (February 2009)

\begin{tabular}{lll}
\hline Name & Destinations 2008 & Network configuration \\
\hline Virgin Blue & $\begin{array}{l}49 \\
\text { (27 Australia, 4 New Zealand, Vanuatu, Cook } \\
\text { Islands, Solomon Islands, Fiji, Tonga, Samoa, } \\
\text { Papua New Guinea, Indonesia) }\end{array}$ & $\begin{array}{l}\text { point-to-point, connecting flights, } \\
\text { feeder (V Australia)* }\end{array}$ \\
& 34 & \\
Jetstar Airways & (22 Australia, 2 New Zealand, 9 Asia, 1 North & point-to-point, feeder (Qantas) \\
& America) & \\
$\begin{array}{l}\text { Tiger Airways } \\
\text { Australia }\end{array}$ & 28 & point-to-point, connecting flights \\
Pacific Blue & c.f. Virgin Blue & \\
* $\begin{array}{l}\text { inauguration March 2009 } \\
\text { Source: } \text { own compilation based on airline websites (status: February 2009); Flight International (2008) }\end{array}$
\end{tabular}

Australia does not have many secondary airports in close proximity to the major cities, which makes competition with the traditional full-service airlines more difficult as in most cases LCCs have to utilise the same primary airports. Avalon airport in Melbourne is a notable exception,

\footnotetext{
5 "Rex has joined forces with Virgin Blue to provide regional travellers with a convenient and cost effective method of flying around the country. Passengers flying on Rex from regional centres to Adelaide, Melbourne and Sydney will be able to remain in the same terminal and connect smoothly to their Virgin Blue destination or vice versa, without the hassle of handling their own bags in between" (Regional Express 2009).
} 
which is used by Jetstar. In several cases, Jetstar has chosen “(...) to avoid head to head competition on routes with Virgin Blue and its parents, Qantas, by flying from a secondary airport" (Forsyth, 2007, p. 92). In contrast, Virgin Blue serves primary airports and competes directly with Qantas.

In New Zealand, there are virtually no alternative airports that are served by LCCs. However, the small airport in Paraparaumu, north of Wellington on the Kapiti Coast, is currently being developed with the establishment of a new terminal and the resealing of the runway (Blundell, 2009). Air New Zealand plans to offer services to Auckland and Christchurch within a year, and the airport has the potential to grow into a secondary (LCC) airport for the Wellington region.

As far as flight distances are concerned, LCCs in Europe have mostly confined themselves to short and medium distance flights with a maximum flight time of approximately 2.5 to 3 hours, in order to achieve a large number of daily rotations. Since direct operational costs per seatkilometer decrease as the flight distance increases, short-distance flights are characterized by an unfavorable relation of ground time to flight time and thus less economical (Sterzenbach and Conrady, 2003). In order to compensate for the disadvantages of relatively short flight distances, LCCs minimize aircraft turnaround times (under 30 minutes) and thus also optimizing the use of the cost-intensive production factor aircraft, quick boarding and no seat assignment, a one-class system (i.e. no separate boarding of business and economy class passengers), no guarantee of connecting flights and consequently no time-critical transfer of luggage, no cargo transport and abandonment or reduction of catering (thus, catering containers have to be exchanged less frequently, or not at all). This system allows LCCs in Europe to keep their aircraft flying up to twelve hours per day and to achieve higher frequencies between two destinations.

LCCs in Australia are challenged with a different set of environmental conditions, compared to LCCs in Europe. Due to the size of the country and its geographical conditions, routes tend to be much longer compared to the routes of European LCCs. Thus short "turnaround" times and "nofrills" (some frills are obligatory on longer flights), important determinants for cost benefits, tend to be less viable.

\section{Personnel Policy}

Due to their concentration on core competencies and related outsourcing operations, European LCCs managed to downsize their workforce to a minimum. Owing to limited onboard services, less in-flight cabin staff is required. Since most of the LCCs have been on the market for a relatively short period of time, and given the fact that they hired staff during economically difficult times and unions rarely were influential, it was possible to achieve low-pay agreements with longer working hours. Other factors which contribute to cutting costs are the maximum utilization of permitted working hours within the legal limits, avoidance of voluntary social charges (such as holiday allowance or Christmas bonus), as well as flight operation with minimum staff. As far as labor contracts are concerned, different national legal regulations are applied in order to employ staff with the most benefits accruing to the LCCs. Employees of Ryanair, for example, are offered contracts subject to Irish employment law, so that employee rights are greatly restricted in comparison to, for example, German ones (Bjelicic, 2004; Goettert and Schmidt, 2005). 
Flying for a buck or two: Low-cost Carriers in Australia and New Zealand

Table 6. Service Classes, Price Discrimination and Range of Services (February 2009)

\begin{tabular}{|c|c|c|c|c|c|c|}
\hline Name & $\begin{array}{l}\text { Service } \text { Classes } \\
\text { (number and } \\
\text { name) }\end{array}$ & $\begin{array}{l}\text { Price } \\
\text { discrimination } \\
\text { (fare name) }\end{array}$ & Seat Pitch & FFP & Inflight entertainment & $\begin{array}{ll}\text { Range of } \\
\text { (e.g. catering) }\end{array}$ \\
\hline $\begin{array}{l}\text { Virgin Blue } \\
\text { and } \\
\text { Pacific Blue }\end{array}$ & $\begin{array}{l}2 \\
\text { Premium Econ- } \\
\text { omy } \\
\text { Standard Econ- } \\
\text { omy }\end{array}$ & $\begin{array}{l}\text { Go! Fare } \\
\text { Blue Saver } \\
\text { Flexible } \\
\text { Corporate Plus } \\
\text { Premium Economy }\end{array}$ & $\begin{array}{l}\text { Premium Economy 33+ } \\
\text { inches }(84 \mathrm{~cm}) \\
\text { Standard Economy 31- } \\
33 \text { inches }(78-84 \mathrm{~cm})\end{array}$ & $\begin{array}{l}\text { Velocity Rewards (with } \\
\text { partner National Australia } \\
\text { Bank offer of a companion } \\
\text { credit card) }\end{array}$ & $\begin{array}{l}\text { monthly in-flight magazine, Live2air } \\
\text { in-flight entertainment ( } 24 \text { live chan- } \\
\text { nels; } \$ 4.95 \text { short flights, } \$ 9.90 \text { longer } \\
\text { flights; advertising channel and flight } \\
\text { track channel free of charge), on } \\
\text { international flights digEplayer } \\
\text { (blockbuster movies, TV shows, } \\
\text { music for a hire fee of } \$ 15 \text { ) }\end{array}$ & not complimentary \\
\hline \multirow[t]{2}{*}{ Jetstar Airways } & $\begin{array}{l}2 \\
\text { Economy } \\
\text { StarClass }\end{array}$ & $\begin{array}{l}\text { JetFlex } \\
\text { JetSaver } \\
\text { JetSaver Light } \\
\text { StarClass }\end{array}$ & $\begin{array}{l}\text { StarClass } 38 \text { inch }(96,5 \\
\mathrm{cm}) \\
\text { Economy class } 30-31 \\
\text { inches }(76-78 \mathrm{~cm})\end{array}$ & $\begin{array}{l}\text { Qantas`FFP for StarClass, } \\
\text { and to a limited extent in } \\
\text { Economy }\end{array}$ & $\begin{array}{l}\text { StarClass: Video on Demand Unit } \\
\text { and headset (movies, TV programs, } \\
\text { music videos) }\end{array}$ & StarClass: complimentary \\
\hline & & & & & $\begin{array}{l}\text { Economy class: limited quantity of } \\
\text { Video on Demand units available for } \\
\text { hire; several screens along the aisles } \\
\text { which will show films and TV pro- } \\
\text { grams; passengers can purchase } \\
\text { reusable headsets; audio programs }\end{array}$ & $\begin{array}{l}\text { Economy class: not compli- } \\
\text { mentary }\end{array}$ \\
\hline Tiger Airways & $\begin{array}{l}1 \\
\text { Economy }\end{array}$ & $\begin{array}{l}\text { Internet Discounted } \\
\text { Fare } \\
\text { Regular Fare }\end{array}$ & 28,5 inches $(72,5 \mathrm{~cm})$ & not available & quarterly in-flight magazine & not complimentary \\
\hline
\end{tabular}

Source: own compilation based on airline websites (status: February 2009); Flight International (2008) 


\section{Marketing}

\section{Product Policy}

The traditional distinction between different booking categories (classes) is not applied by most European LCCs. Australian/New Zealand LCCs generally offer two classes (one standard economy, and one premium class), with the exception of Tiger Airways (Table 6). Virgin Blue is now promoting a more differentiated "New World Carrier" strategy, a business plan which is aimed at the contemporary business traveller. In this regard Virgin Blue Airlines recently launched Australia's first "Premium Economy" product (Centre for Asia Pacific Aviation, 2008).

Seat density, which is a product feature, is determined according to principles designed to optimize revenue. Tighter seating (typical seat pitch is 29-30 inches instead of the usual 31-34 inches with traditional airlines) leads to a reduction of product quality, while allowing an increase in capacity. Consequently, costs per seat and flight prices drop and the priority service feature desired by customers (i.e., low cost) is achieved (Sterzenbach and Conrady, 2003). Virgin Blue, Pacific Blue, and Jetstar offer a seat pitch of at least 30-31 inches on their newer airplanes, which is a comparatively large seat pitch for a LCC (Table 6). Virgin Blue, Pacific Blue and Polynesian Blue have a so-called "Blue Zone". For an additional charge (\$AUD 25-45), passengers can pre-reserve an extra roomy over-wing exit row seat on Virgin Blue's Embraer E190, and Virgin Blue, Pacific Blue and Polynesian Blue Boeing 737 aircraft. The "Blue Zone" seating offers the equivalent of a 39 inch seat pitch.

Table 7. Seating Density (February 2009)

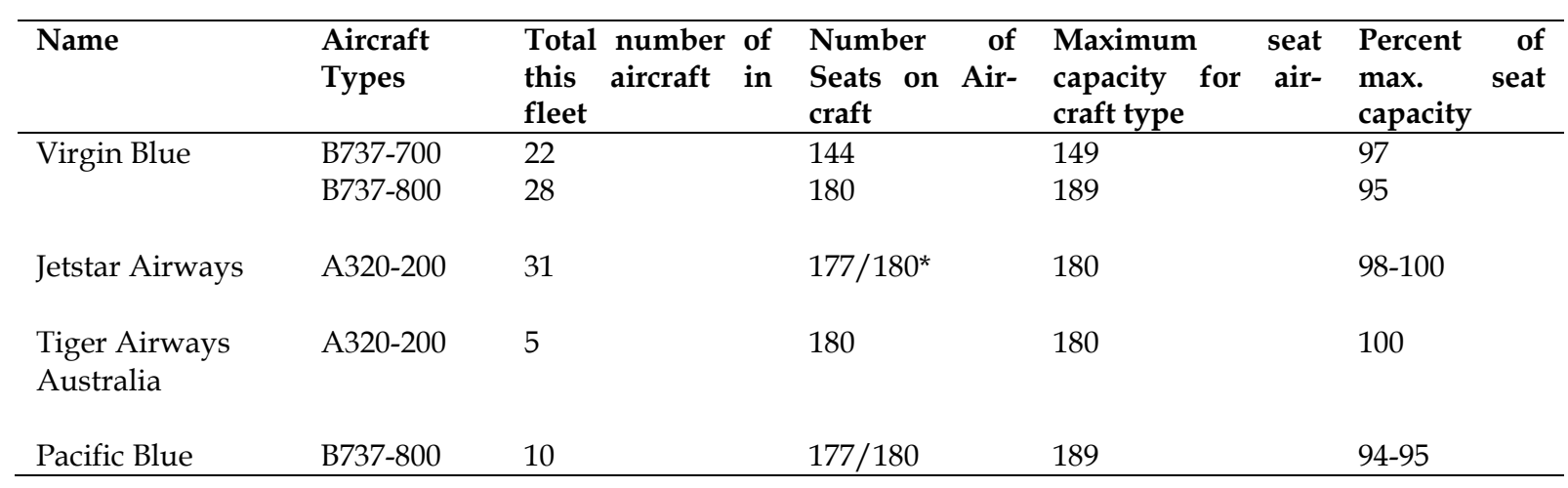

* 177 passengers within Australia and New Zealand and 180 passengers on intra Asia flights

Source: own compilation based on airline websites (status: February 2009)

Seat density describes the total actual number of seats of an aircraft, compared with the total number of seats possible (as per manufacturer). The total maximum capacity at which the airline operates the aircraft is calculated as a percentage. Table 7 shows that the airlines operating with $100 \%$ capacity are Jetstar and Tiger Airways. Surveys show that successful LCCs in Europe (e.g. Ryanair, easyJet, FlyBe.com) have similar seat densities. A study by Edwards (2008, p. 7) argues "that FSCs operate their aircraft at as much as 33\% less than the maximum capacity levels employed by the highest-ranking LCC". $^{\prime}$.

Frequent flyer programs are part of the standard services offered by traditional airlines. Since cost reduction is given priority by LCCs and those programs involve high administration costs, most European LCCs have not yet introduced such programs (exceptions are, for example, Air Berlin, TUIFly or germanwings). In contrast, all LCCs in Australia and New Zealand operating 
within the domestic market (with the exception of Tiger Airways) offer an own frequent flyer program or participate in an external scheme (Table 6).

\section{Pricing Policy}

Since the feature of "low fares" is the most important feature for consumers, pricing represents the most powerful marketing instrument for LCCs in Europe, while being a long-term factor for customer loyalty. For pricing LCCs use a mixed calculation, i.e. the average ticket price determined by cost accounting procedures serves as a basis for the offered prices. Flights are sold at different prices with some of the tickets undercutting network/legacy carriers significantly and being distributed at a loss, which in turn is compensated for by high-priced tickets, often exceeding the fares of network/legacy carriers. In contrast to traditional pricing policy, a time-related price discrimination is implemented through penetration pricing.

At first low base prices (initial prices) corresponding to the strategic pricing policy aims are determined, i.e. market-orientated pricing based on competition and demand is undertaken. These base prices are communicated to the consumers in order to encourage them to book early. In contrast to "last-minute prices", which are perceived by customers as being reduced as time goes on thus increasing the risk of booked out flights, this price system conveys to the customer the idea of a "price guarantee", i.e. there will be no cheaper prices for a certain flight at a later point in time. As booking goes on, pricing becomes more cost-orientated and prices increase as the departure date draws closer. There may be a constant increase in prices, or prices may be adjusted according to the revenue management parameters (e.g. booking details from the past, prognostics or price flexibilities) and the actual booking situation.

Consequently LCCs practice a dynamic and flexible pricing policy with a mixture of cost- and market-orientated elements. In a first step a specific low-price contingent is determined. Its size varies from one airline to another, comprising between $10 \%$ and $70 \%$ of the offered seats, and averaging $20-30 \%$ (Ramm, 2002). When this contingent is sold prices increase in steps and may reach, or even go beyond, the prices of traditional airlines.

Table 8. Fare Comparison for Selected Trans-Tasman Routes/Dates (in $\$ N Z$ as per 29.03.2010)

\begin{tabular}{llllll}
\hline & NZ & QF & DJ* $^{*}$ & JQ** $^{* *}$ & Expedia \\
\hline AKL-OOL & & & & & \\
$\begin{array}{l}\text { 1.5.-10.5.2010 } \\
\text { 31.10.-10.11.2010 }\end{array}$ & $\$ 530.80$ & $\$ 711.00^{* * *}$ & $\$ 362.00$ & $\$ 427.87$ & $\$ 362.00(\mathrm{DJ})$ \\
$\begin{array}{l}\text { AKL-SYD } \\
\text { 1.5.-10.5.2010 }\end{array}$ & $\$ 382.50$ & $\$ 423.00$ & $\$ 319.90$ & $\$ 392.42$ & $\$ 319.00(\mathrm{DJ})$ \\
$\begin{array}{l}\text { 1.11.-10.11.2010 } \\
\text { AKL-MEL }\end{array}$ & $\$ 423.50$ & $\$ 508.00$ & $\$ 419.90$ & $\$ 382.42$ & $\$ 419.90(\mathrm{DJ})$ \\
$\begin{array}{l}\text { 1.5.-10.5.2010 } \\
\text { 1.11.-10.11.2010 }\end{array}$ & $\$ 382.50$ & $\$ 450.00$ & $\$ 440.00$ & no service & $\$ 420.00(\mathrm{DJ})$ \\
\hline
\end{tabular}

Key: NZ = Air New Zealand, QF = Qantas (including its subsidiary *JetConnect), DJ = Pacific Blue, EK = Emirates, JQ = Jetstar

$\mathrm{AKL}=$ Auckland; $\mathrm{OOL}=$ Coolangatta $/$ Gold Coast; $\mathrm{SYD}=$ Sydney; $\mathrm{MEL}=$ Melbourne

${ }^{*} \mathrm{DJ}$ charges a $\$ 5$ fee for payment by credit card or debit card in addition to the published fare

**JQ charges $\$ 20$ for a checked bag in addition to the published fare

*** QF does not offer non-stop services to OOL. Fares are for AKL-SYD on QF and SYD-OOL on JQ 
The pricing of LCCs in Australia and New Zealand is less transparent. After the emergence of LCCs (Pacific Blue and Freedom Air) on the trans-Tasman routes, it is estimated that the seat capacity grew by $24 \%$, while fares dropped by $30-50 \%$ (Collier, 2006). However, after the initial price war, fares seem to have settled and appear to be set by LCCs to match competitors' fares, and often only slightly undercut these. The extreme gaps between the lowest and the highest fares, as is common in Europe (Table 8), seem not to exist. Similar to European LCCs, but not to the same extent, there are hidden fees with LCCs, such as a $\$ 5$ credit card fee (Pacific Blue), and a \$20 baggage fee (Jetstar).

At the time LCCs in Europe emerged, there was typically one single price for a certain flight at a certain point of time. During the last few years this system has softened, and today, carriers like TUIfly, germanwings and Air Berlin offer true low fare tickets and flexible fares with significant price differences (TUIfly: Smile fare and Flex fare, germanwings: Basic and FlexPlus, Air Berlin: Spar and Flex). Most LCCs in Australia and New Zealand also offer different fares with specific terms and conditions, as illustrated in Table 6. After having undertaken extensive market research, Air New Zealand recently announced a new fare structure across the Tasman, which is a mix of no frills (classic LCC) and full service fares. Air New Zealand will offer four different fares (Seat, Seat+Bag, The Works, and Works Deluxe) (Table 9).

Table 9. New Air New Zealand Trans-Tasman Fares (to be gradually introduced from August 2010)

\begin{tabular}{|c|c|c|c|c|}
\hline & Seat & Luggage & Entertainment & Catering \\
\hline Seat & $\begin{array}{l}\text { Standard economy } \\
\text { seat }\end{array}$ & 1 carry-on bag $(7 \mathrm{~kg})$ & $\begin{array}{l}\text { Free: TV shows, mu- } \\
\text { sic, games } \\
\text { Pay-to-view: Movies }\end{array}$ & $\begin{array}{l}\text { Free: Tea, coffee, } \\
\text { water } \\
\text { Food for Purchase: } \\
\text { Snacks, drinks }\end{array}$ \\
\hline Seat+Bag & $\begin{array}{l}\text { Standard economy } \\
\text { seat }\end{array}$ & $\begin{array}{l}1 \text { carry-on bag }(7 \mathrm{~kg}) \\
\text { and } 1 \text { checked bag } \\
(23 \mathrm{~kg})\end{array}$ & $\begin{array}{l}\text { Free: TV shows, mu- } \\
\text { sic, games } \\
\text { Pay-to-view: Movies }\end{array}$ & $\begin{array}{l}\text { Free: Tea, coffee, } \\
\text { water } \\
\text { Food for Purchase: } \\
\text { Snacks, drinks }\end{array}$ \\
\hline The Works & $\begin{array}{l}\text { Standard economy } \\
\text { seat (incl. seat re- } \\
\text { quest) }\end{array}$ & $\begin{array}{l}1 \text { carry-on bag }(7 \mathrm{~kg}) \\
\text { and } 1 \text { checked bag } \\
(23 \mathrm{~kg})\end{array}$ & $\begin{array}{l}\text { Free: TV shows, mu- } \\
\text { sic, games, movies }\end{array}$ & $\begin{array}{l}\text { Free: Full meal and } \\
\text { beverages (with } \\
\text { meal service) }\end{array}$ \\
\hline Works Deluxe & $\begin{array}{l}\text { Standard economy } \\
\text { seat (incl. seat re- } \\
\text { quest), "next seat } \\
\text { empty guarantee", } \\
\text { lounge access }\end{array}$ & $\begin{array}{l}1 \text { carry-on bag }(7 \mathrm{~kg}) \\
\text { and } 2 \text { checked bags } \\
\text { (23kg each) }\end{array}$ & $\begin{array}{l}\text { Free: TV shows, mu- } \\
\text { sic, games, movies }\end{array}$ & $\begin{array}{l}\text { Free: Full meal and } \\
\text { beverage service } \\
\text { throughout entire } \\
\text { flight }\end{array}$ \\
\hline
\end{tabular}

Source: http://www.airnewzealand.co.nz/new-tasman-and-pacific-service/ 
Table 10. Method of Booking/Check-in Services

\begin{tabular}{|c|c|c|c|c|c|c|c|c|}
\hline & \multicolumn{4}{|c|}{ Method of booking } & \multicolumn{4}{|l|}{ Check-in } \\
\hline & $\begin{array}{l}\text { Inter- } \\
\text { net }\end{array}$ & $\begin{array}{l}\text { Call } \\
\text { centre }\end{array}$ & GDS & $\begin{array}{l}\text { Inter- } \\
\text { mediaries }\end{array}$ & $\begin{array}{l}\text { Online free } \\
\text { seat selec- } \\
\text { tion }\end{array}$ & $\begin{array}{l}\text { Online } \\
\text { chargeable } \\
\text { seat selection }\end{array}$ & $\begin{array}{l}\text { Tele- } \\
\text { phone }\end{array}$ & $\begin{array}{l}\text { Self- } \\
\text { Service } \\
\text { Kiosk }\end{array}$ \\
\hline $\begin{array}{l}\text { Virgin } \\
\text { Blue }\end{array}$ & $\checkmark$ & $\checkmark$ & $\checkmark$ & $\checkmark$ & $\checkmark$ & $\mathrm{N} / \mathrm{A}$ & $\mathrm{N} / \mathrm{A}$ & $\checkmark$ \\
\hline $\begin{array}{l}\text { Jetstar } \\
\text { Airways }\end{array}$ & $\checkmark$ & $\checkmark$ & $\checkmark$ & $\begin{array}{l}\checkmark \quad \text { (under } \\
\text { QF flight } \\
\text { number) }\end{array}$ & $\checkmark$ & $\mathrm{N} / \mathrm{A}$ & $\mathrm{N} / \mathrm{A}$ & $\mathrm{N} / \mathrm{A}$ \\
\hline $\begin{array}{l}\text { Tiger } \\
\text { Airways } \\
\text { Australia }\end{array}$ & $\checkmark$ & $\checkmark$ & $\checkmark$ & $\mathrm{N} / \mathrm{A}$ & $\mathrm{N} / \mathrm{A}$ & $\checkmark$ & $\mathrm{N} / \mathrm{A}$ & $\mathrm{N} / \mathrm{A}$ \\
\hline $\begin{array}{l}\text { Pacific } \\
\text { Blue }\end{array}$ & $\checkmark$ & $\checkmark$ & $\checkmark$ & $\checkmark$ & $\checkmark$ & $\mathrm{N} / \mathrm{A}$ & $\mathrm{N} / \mathrm{A}$ & $\checkmark$ \\
\hline
\end{tabular}

$\checkmark=$ Airline offers service (in at least one area of its operations), N/A = service is not available

Source: Own compilation based on airline websites (status: February 2009)

\section{Distribution Policy}

LCCs in Europe sell their services through few distribution channels, mainly directly through the Internet or booking machines (direct self-distribution) or through their own centralized call centers established at cost-competitive locations. More savings of distribution costs are achieved by issuing tickets together with the boarding pass, and by using electronic tickets. Printing and material costs are even shifted onto the passengers (e.g. print-out of tickets/boarding passes). The collection of payment, which has traditionally been through intermediaries or special accounting agencies (e.g. Airplus), is practiced cost-effectively through credit and debit cards, creating a positive impact on the LCCs' solvency situation (Pompl, 2007). Virgin Blue and Tiger Airways, for example, have an effective distribution model: over 90\% (Virgin Blue) and 85\% (Tiger Airways) of tickets sold are via the Internet (InvestSMART 2009, Tiger Airways 2009). In comparison to Europe, all LCCs in Australia/New Zealand are bookable via Global Distribution Systems (GDS), and some via intermediaries (such as Expedia), as illustrated in Table 10.

\section{Communication Policy}

The communication policy is designed to inform (potential) customers about the available services offered by a LCC. Public relations work is partly carried out through spectacular campaigns, helping LCCs attract great public interest and gain free publicity. Sales promotion should be considered in close relationship with this. This includes enabling of both self- and third-party distribution channels, while it is also directed towards the end consumer. European LCCs run various sales promotion campaigns such as the sale of tickets at a symbolic price (e.g. for one cent) or giving away tickets free of charge. Furthermore, communication is practiced through intensive advertising addressed to the end consumer. Advertising focuses on the price, most of the time mentioning only the net price. Any extra charges such as general taxes, handling or safety duties, and fuel surcharges are charged separately and not mentioned at all or only as a footnote in advertisements. LCCs prefer advertising in daily newspapers ("daily prices need a daily press"). The communication concept incorporates both classical advertising through selective presence in relevant markets and the use of modern information technologies. But there are also innovative approaches which are being followed by low cost airlines. On British TV there is, for example, a documentary series run by easyJet ("Airline"), which is about the life of passengers and staff of the airline. After it had reached an audience of 75 million viewers in the UK, it was sold to other countries (e.g. New Zealand, Australia, Japan). In addition to corporate behavior 
and corporate communication, the corporate identity encompasses the external image (corporate design) including the branding of aircraft. LCCs use the fuselage to communicate booking phone numbers (easyJet) or Internet domains (volare.web).

These communication instruments can also be implemented by airlines in Australia and New Zealand. For example, Jetstar pursues innovative approaches in their communication policy with its own TV series ("Going Places"), and is the major sponsor of a National Rugby League team (the Jetstar Gold Coast Titans) and the Australian program "The Morning Show". The use of airplanes as advertising space for third companies was, for example, put into action by Jetstar (pizza advertisement). Jetstar also provided sponsorship to Australian Football League (AFL) matches held in Tasmania, was a corporate partner of the Geelong Football Club's football volunteer program, and is a major supporter of the Tasmanian Symphony Orchestra and its school education program (Qantas, 2008).

While LCCs were the pioneers of such communication strategies, several network/legacy carriers followed suit. Air New Zealand is sponsoring rugby, and aggressively communicates this in TV commercials and print media. Air New Zealand also launched a new marketing campaign under the title "we have nothing to hide". The TV commercials, featuring Air NZ staff (including the CEO Rob Fyfe) nude with uniforms painted on their bodies, has been picked up by the media, discussion groups, and blogs worldwide. The commercials are available on YouTube, and even the inflight safety video now features nude/body-painted Air NZ cockpit and cabin crew. The campaign became so successful that Air NZ even dedicated an own website to it: http://www.nothingtohide.co.nz/

\section{Conclusion}

The LCCs in Australia and New Zealand are another example of the worldwide trend towards airlines offering heavily discounted fares, although the fare level across the Tasman appears to have settled after the initial price war in the mid-1990s. The local airline market has initially been dominated by the national airlines Qantas and Air New Zealand for many years. However, after some unsuccessful initial attempts (e.g., Impulse Airlines, Kiwi Airlines), the last decade has witnessed a major restructuring. The former duopoly of Qantas and Air New Zealand was stirred up by the emergence of LCCs significantly lowering fares. These discounted airfares have generated additional competition, providing greater deals for consumers. In addition the consumer benefits from flexible fare structures, i.e. whether to pay additional fees for luggage, catering, and entertainment. This has made air travel more attractive and will further accelerate the positive growth rates in the tourism industries in Australia and New Zealand. In a liberalized and more competitive environment the new LCCs achieved significant market shares of the region's aviation industry in just a few years. Legacy carriers responded in different ways. While Qantas is increasingly withdrawing from the trans-Tasman market (and operates these routes through their LCC subsidiary Jetstar), Air New Zealand re-integrated Freedom Air into their mainline operations, and introduced various fare products across the Tasman in 2010, from seat-only fares to full service fares. However, in a move to respond to the Qantas/Jestar strategy, Air New Zealand and Pacific Blue have recently announced a comprehensive cooperation including an extensive code share agreement (Pacific Blue, 2010).

Having started as a low complexity, low cost airline, Virgin Blue evolved into an integrated air services provider. It benefits from a highly competitive cost structure, a modern and efficient fleet, flexible workplace arrangements and an effective and streamlined distribution model. It established a comprehensive domestic network with connectivity, great flight frequencies, a loyalty programme, lounges and other customer services, and already launched two international joint ventures. Pacific Blue is acting on the New Zealand market, whereas Polynesian Blue oper- 
ates to/from the Pacific islands. Tiger Airways remains the only "real" no-frills airline (e.g. one aircraft model, one booking class, no services included, no in-flight entertainment except of an inflight magazine).

The future development of the low cost business is expected to generate further demand on the trans-Tasman routes as well as increasing international outbound travel to other countries worldwide. Many LCCs have already altered airline strategies, offering long-haul routes to Asia, North America, and South Africa (e.g., V Australia, Jetstar). The use of secondary airports, primarily in Australia, could provide favourable conditions (not/less capacity restricted, lower costs, more convenient for passengers) for the further rise in LCCs in the region.

It is evident that the airline market in Australia and New Zealand has significant growth potential. LCCs will play a major role in this, but especially Air New Zealand is not shy in counteracting and offering similar products, both domestically, and across the Tasman. The fierce competition means it will be particularly difficult for new entrants to survive in this industry.

The analysis of the business models in Australia and New Zealand showed that the LCCs in that region adopted a number of product developments, as well as service offerings (for purchase), deviating from their counterparts in Europe, North America and Asia. However, both across the Tasman Sea, one of the most competitive aviation markets in the world, as well as in their respective domestic markets, fares have not reached a similarly low level. With distances requiring flight times of more than three hours across the Tasman, and up to five hours domestically in Australia, such low fares are not financially viable. On the other hand, with a population just over four million in New Zealand, and just over 21 million in Australia, the potential markets are significantly smaller than in Europe (731 million) and North America (529 million). While LCCs in Oceania could learn a great deal from their more experienced counterparts in Europe, European LCCs can now in turn gain valuable information from LCCs who operate in different environments, such as the adaptation of a LCC to a longer short haul to medium haul operations.

\section{References}

Airobserver (2009). Pressure, lies and demagogy: easyJet and Ryanair's communication. Online at http://www.zimbio.com/Ryanair/articles/dfXLVMADrfA/Pressure+lies+demagogy+easyJet+Ryan air+communication (Last access 17-03-2010)

Allo' Expat (2009). International Airport in Australia. Online document at http://www.australia.alloexpat.com/australia_information/international_airport_australia.php (Last access 05-02-2009)

Avalon Airport (2010). Avalon Airport at a Glance. Online documents at URL http://www.avalonairport.com.au/ (Last access 26-03-2010)

Berster, P. and Wilken, D. (2005). Netzentwicklung, Marktdurchdringung und Verkehrsgenerierung der Low Cost Carrier Deutschlands im Verkehr Europas. Proceedings zu den 20. Verkehrswissenschaftlichen Tagen der TU Dresden, Dresden.

Bieger, T. and Agosti, S (2006). Business Models in the Airline Sector - Evolution and Perspectives, in Delfmann et al. (eds) Strategic Management in the Aviation Industry, Hampshire, Ashgate.

BITRE - Bureau of Infrastructure, Transport and Regional Economics (2006). Aviation Statistics: Airport Traffic Data 1995-96 to 2005-06, Canberra.

BITRE - Bureau of Infrastructure, Transport and Regional Economics (2008a). Air passenger movements through capital city airports from 2025-26. Online document at URL

http://www.bitre.gov.au/publications/37/Files/WP72.pdf (Last access 06-02-2009) 
BITRE - Bureau of Infrastructure, Transport and Regional Economics (2008b). Aviation Statistics: Airport Traffic Data 1997-98 to 2007-08. Online documents at URL

http://www.bitre.gov.au/publications/90/Files/AirportPublication2007-08.pdf (Last access 06-022009)

Bjelicic, B. (2004). Osteuropa - Wachstumsmarkt für Low Cost Airlines. Internationales Verkehrswesen, vol. 56, no. 7/8, pp. 309-313.

Blundell, K. (2009). \$450m Paraparaumu Airport project lifts off. Online documents at URL http:// www.stuff.co.nz/travel/2833160/450m-Paraparaumu-Airport-project-lifts-off (Last access 1703-2010)

Boeing (2007). Current Market Outlook 2007. Online documents at URL http://www.boeing.com/commercial/cmo/pdf/Boeing_Current_Market_Outlook_2007.pdf (Last access 12-06-2008)

Business Day (2009). Jetstar add extra planes to its Christchurch fleet. Online document at URL http:// www.stuff.co.nz/4310735a13.html (Last access 08-03-2009)

Cento, A. (2009). The Airline Industry - Challenges in the 21st Century. Heidelberg, PhysicaVerlag/Springer.

Centre for Asia Pacific Aviation (2008). Virgin Blue launches 'Premium Economy' product. Online http:// peanuts.aero/low_cost_airline_news/airline/8126/59/Virgin+Blue+launches+\%E2\%80\%98Pr emium+Economy $\% \mathrm{E} 2 \% 80 \% 99+$ product (Last access $09-02-2009$ )

Collier, A. (2006). Principles of Tourism: A New Zealand Perspective. Auckland, Pearson Hospitality Press.

Deutsches Zentrum für Luft- und Raumfahrt (DLR) and Arbeitsgemeinschaft Deutscher Verkehrsflughäfen (ADV) (2008). Low Cost Monitor 2/2008. Cologne, Berlin.

Edwards, J. (2008). What Is A Low Cost Airline? Defining Carrier Business Models. Proceedings of the Air Transport Research Society (ATRS) World Conference. 6th to 10th July 2008 in Athens/Greece.

Flight International (2008). World Airlines Directory 2007. Sutton, Stroud/UK.

Forsyth, P. (2003). Low-cost carriers in Australia: experiences and impacts. Journal of Air Transport Management, no. 9, pp. 277-284.

Forsyth, P. (2007). Predatory Behaviour in Australian Aviation Markets. In Forsyth et al. (eds) Competition versus Predation in Aviation Markets - A Survey of Experience in North America, Europe and Australia, Ashgate, Hampshire.

Francis, G., Humphreys, I., Ison, S. and Aicken, M. (2006). Where next for low cost airlines? A spatial and temporal comparative study. Journal of Transport Geography, no. 14, pp. 83-94.

Goettert, J.-M. and Schmidt, L. (2005). Irischer Geizhals. FVW International, no. 30, 66-69.

Graham, A. (2003). Managing Airports: An international perspective. Oxford, Elsevier ButterworthHeinemann.

Gross, S. and Schroeder, A. (2007). Basic Business Model of European Low Cost Airlines - An Analysis of Typical Characteristics. In Gross, S. and Schroeder, A. (eds) Handbook of Low Cost Airlines - Strategies, Business Processes and Market Environment, Erich Schmidt Publishing, Berlin.

Harbison, P. And McDermott, P. (2009). Global LCC Outlook Report: The World has changed. Sydney, Centre for Asia Pacific Aviation.

Hazledine, T. (2008). Competition and Competition Policy in the Trans-Tasman Air Travel Market. The Australian Economic Review, no. 4, pp. 337-348. 
Horbert, M. (2007). Airports in the Process of Change - A Contemporary Business Model in a Low Cost Age. In Gross, S. and Schroeder, A. (eds) Handbook of Low Cost Airlines - Strategies, Business Processes and Market Environment, Erich Schmidt Publishing, Berlin.

InvestSMART (2009). Virgin Blue Holdings Limited (VBA). Online document at URL https:// www.investsmart.com.au/company_profile/summary/default.asp?SecurityID=VBA\&Excha ngeID=ASX (Last access 11-02-2009)

Ministry of Transport New Zealand (2007). Mutual Recognition of Aviation-Related Certification with Australia. Online document at URL http://www.transport.govt.nz/mutual-recognition-1 (Last acess 04-02-2009)

Pacific Blue. (2010). Virgin Blue Airlines Group and Air New Zealand [Press Release]. Online document at URL http://www.flypacificblue.com/AboutUs/Media/NewsandPressReleases/P_012222.htm (Last access 01-06-2010)

PhoCusWrigt (2007). PhoCusWrigt's Australia/new Zealand Online Travel Overview. Online at http://www.phocuswright.com/research_publications_buy_a_report/358 (Last access 05-02-2009)

Pompl, W. (2007). Luftverkehr - Eine ökonomische und politische Einführung. Springer Publishing, Berlin.

Pranger, K. (2005). Billigflieger: Brüssel will Subventionen an den Airports begrenzen. touristik aktuell, no. $8 / 9$, p. 31 .

Qantas Airways (2007). Qantas announces profit result for year ended 30 June 2007 and an-market share buyback. Online document at URL

http://www.jetstar.com/ /media/files/pdf/news/2007/aug/20070816.pdf (Last access 04-02-2009)

Qantas Airways (2008). Annual Report 2008, Mascot.

Ramm, T. (2002). Germanisch fliegen. Touristik Report, no. 20, p. 10.

Regional Express (2009). Booking Info - Interline Agreements. Online document at URL http://www.regionalexpress.com.au/FlightInfo/InterlineAgreements.aspx (Last access 09-02-2009)

Statistics New Zealand (2009). Civil Aviation. Online document at URL http://www2.stats.govt.nz/domino/external/web/nzstories.nsf/0/d94ee48e2b473672cc256b1f00042 455? OpenDocument (Last access 30-01-2009)

Sterzenbach, R. and Conrady, R. (2003). Luftverkehr - Betriebswirtschaftliches Lehr- und Handbuch. Oldenbourg Publishing, Munich/Vienna.

Stirm, P. and Schmidt, L. (2005). Zu viele Flügel am Himmel. FVW International, no. 17, pp. 76-78.

T2Impact and Flight Insight (2008). The Future of Low Cost Carriers: Current thinking, strategic analysis and market evolution. T2Impact and Flight Insight, London and Sutton, Surrey (UK).

Teckentrup, R. (2009). Low-Cost-Airlines Aus Sicht Von Charter-Airlines. In Bastian, H.; Dreyer, A. \& Gross, S. (eds.) Tourismus 3.0: Fakten und Perspektiven. Hamburg, ITD Verlag.

Tere, Juhan (2010). Ryanair is pressuring Tallinn Airport to lower airport fees. Online document at URL http:// www.baltic-course.com/eng/transport/?doc=24506 (Last access 17-03-2010)

Tiger Airways (2009). Company Overview. Online document at URL http://www.tigerairways.com/au/en/about_us.php (Last access 09-02-2009)

Tourism Australia (2008a). International Visitors in Australia - September 2008 Quarterly Results of the International Visitor Survey.

Tourism Australia (2008b). New Zealand Aviation Profile. Online document at URL http://www.tourismaustralia.com/content/New\%20Zealand/profiles_2008/Aviation $\% 20$ profiles $\% 2$ 02008-\%20NZ\%20[Compatibility\%20Mode].pdf (Last access 06-02-2009) 
Flying for a buck or two: Low-cost Carriers in Australia and New Zealand

Tourism New Zealand (2008). Australia Market Overview. Online document at URL http://www.tourismnewzealand.com/tourism_info/market-research/marketguides/australia/market-snapshot-australia.cfm (Last access 06-02-2009)

Tourism New Zealand (2009). New Zealand Airports. Online document at URL http://www.newzealand.com/travel/getting-to-around-nz/getting-tonz/airports/airports_home.cfm (Last access 06-02-2009)

Virgin Blue (2006). Hawaiian Airlines And Virgin Blue Make Hawaii Travel Easier From All Of Aus-

Online document at

URL http://www.virginblue.com.au/AboutUs/Media/NewsandPressReleases/U_001186.htm (Last access 09-02-2009)

Wilson, E. (1996). Dogfight: The inside story of the Kiwi Airlines collapse. Auckland, Howling at the Moon Productions. 